\title{
A REVIEW OF HOW BEHAVIOURAL INSIGHTS HAVE BEEN APPLIED TO TAX-RELATED POLICY AND FIELD EXPERIMENTS IN THE EUROPEAN UNION
}

Tax evasion is a problem in every country. Since taxes are the most important source of income for the state budget, finance ministers and tax authorities strive to increase tax compliance and secure higher tax revenues. In the context of European Union objectives to monitor the effects of behavioural insights and gather information for critical evaluation, this article contributes to these efforts by summarizing policies and measures related to increasing tax compliance. This article is based on a systematic review and is complemented by other relevant sources related to applying behavioural insights to tax policy. The article concludes that although there is empirical evidence to suggest that behaviourally informed initiatives and interventions have had a significant impact on tax compliance in the short term, there is not enough evidence to draw conclusions on the long-term effects. In addition, the real motives and causal mechanisms that have led to increased tax compliance are not entirely clear. The results of the research suggest that deterrence is an important factor. Although deterrence might increase tax compliance, it is uncertain whether it has any positive effect on tax morale in general. The article raises the argument that many behaviourally-informed techniques are actually based on deterrence. In this respect, the article calls for further research to reveal the real effects of behavioural insights. Further work on reviewing and evaluating research results will also be important, as individual

* M. Müller, Ph.D., Palacký University Olomouc, Faculty of Arts, Department of Economic and Managerial Studies (e-mail: michal.muller@upol.cz). The paper was received on 24.04.2019. It was accepted for publication on 14.07.2020. 
initiatives across EU countries are not easily traceable. This fact represents the limits of this study and highlights opportunities for future research.

Keywords: Behavioural Public Finance, the European Union, Tax Amnesty, Tax Evasion, Tax Compliance, Tax Policy

\section{INTRODUCTION}

Tax and tax laws represent a complex issue that is not typically at the centre of interest for ordinary taxpayers (Kirchler, 2009, p. 28). How taxpayers react to tax is influenced by their resources. Most people do not understand the relationship between tax and behaviour, as described in economic theory. Taxpayers respond to taxes according to how they perceive them, not necessarily as policymakers assume (Congdon, Kling \& Mullainathan, 2011, pp. 190-197). Behavioural research can help policymakers understand taxpayer responses, and this knowledge can be used to create tools that can increase tax compliance, make education more effective, inform about the importance of tax, and ultimately reduce tax evasion.

As in other developed countries, EU member states also try to apply behavioural research to increase tax compliance. The most widespread techniques are based on applying behavioural insights to tax policies and conducting field experiments. Compared with laboratory experiments and questionnaire surveys, field experiments with behavioural insights provide information on the impact of these methods on actual taxpayer behaviour. Advances in science and in understanding the mechanisms of human behaviour have led to increased use of behavioural insights in practice. However, much work and research has yet to be done to assess the real impact of these applications with certainty. This is also reflected in the European Union by the European Economic and Social Committee (OJ C75, 2017). This article is inspired by the recommendations of the European Economic and Social Committee to promote the exchange of information related to nudges and behavioural insights and to study them in greater depth, particularly the duration of the effect of these measures, possible negative impacts, and ethical issues. This article therefore aims to provide a review of tax-related behavioural implementations and field experiments within the EU. This paper follows reports on behavioural insights published by the European Commission (Lourenço et al., 2016) and further develops it into an academic article that provides a better framework for critical discussion on the impact of individual measures.

Critical discussion is very important, as it turns out that measures that are beneficial in the short term and result in rapid tax revenue can have negative consequences in the long run. In addition to reviewing individual measures inspired by 
behavioural insights, this article discusses these challenging aspects of tax policy. The paper contributes to the discussion by arguing that several behaviourally informed techniques are actually based on deterrence. It is also important to note the ethical aspects of each individual measure. In this respect, it is argued that, long term, education is particularly important for increasing tax morale.

The first part of this article reviews tax-related behavioural insights as applied within European Union member states. In this section, initiatives such as introducing receipt lotteries, educational campaigns, simplified tax returns, and tax amnesties are mentioned. The knowledge gained in behavioural research can be used in all of these areas. The second part reviews tax-related field experiments in the EU.

\section{METHODOLOGY}

Prior to the start of the research, an analysis of reports published by the European Commission was conducted. Specifically, "Behavioural Insights Applied to Policy: European Report 2016" (Lourenço et al. 2016) was important in this respect. This text takes the form of a simplified report. In several cases it does not reference original research papers which makes it difficult to follow up on critically. However, the text provides a basic outline of individual policies within the EU which we extended to additional categories throughout this paper. In addition, the sources from which the original report was drawn from were examined and the relevant information updated. For this purpose, the EBSCO database was used. Additional discovery on the web pages that are administered by the ministries of finance of the Member States of the European Union was though Google search. This search enabled us to find information related to receipt lotteries and the various online tools used to increase tax compliance. Working papers that are not indexed in the Web of Science (WoS) and Scopus databases have also been found in this way. This phase of our research represents the most serious limitations of the study as purposive sampling had to be used due to the diversity of resources.

The next phase of the research was a systematic review. Relevant sources for review were found through the Web of Science (WoS) and Scopus databases. Inclusion criteria were based on the following keywords: "tax compliance", "tax perception", "tax behavioural insights", "receipt lottery", "tax lottery", "tax amnesty", "tax field experiment", and "tax reminder". Another inclusion criterion was the geographical limitation to EU and Schengen countries. Articles that were not related to behavioural insights and their applications were discarded. While searching in WoS, the "All fields" search category was enabled. In Scopus "Article title", 
"Abstract", and "Keywords" search categories were enabled. The results of the search are shown in Table 1. Even this systematic approach has its limitations, as relevant articles may not be found with the chosen keywords since other keywords can be defined for those articles by the authors. This is simply due to the diversity of individual instruments in tax policy. This article focuses on the implementation of behavioural insights and on the results of field experiments. The review therefore does not include laboratory and other experiments, statistical analyses, questionnaire surveys, or psychological investigations that do not have a practical impact on tax collection. Despite the large number of studies within each keyword search, only 30 articles meet the latter criteria. This suggests that our purposive sampling is a justified procedure, even though it has its limitations. Other sources that have been used complement the context and develop a discussion of the effects of behavioural insights in tax policy.

Table 1.

\section{NUMBER OF ARTICLES INDEXED IN THE WEB OF SCIENCE AND SCOPUS DATABASES INCLUDED IN THE REVIEW}

\begin{tabular}{|c|c|c|c|c|c|c|c|c|}
\hline & \multicolumn{8}{|c|}{ Keywords inclusion criteria } \\
\hline & KW1 & KW2 & KW3 & KW4 & KW5 & KW6 & KW7 & KW8 \\
\hline Web of Science (all fields) & 2101 & 1337 & 42 & 98 & 227 & 96 & 273 & 41 \\
\hline $\begin{array}{l}\text { Scopus (abstract, title, } \\
\text { keywords) }\end{array}$ & 2695 & 1548 & 62 & 33 & 193 & 82 & 172 & 33 \\
\hline $\begin{array}{l}\text { Geographical criteria, } \\
\text { relation to behavioral } \\
\text { insights }\end{array}$ & 18 & 3 & 2 & 2 & 8 & 8 & 22 & 2 \\
\hline $\begin{array}{l}\text { Total number after exclusion } \\
\text { of duplicate search results } \\
\text { within keyword }\end{array}$ & 13 & 3 & 2 & 2 & 6 & 6 & 14 & 1 \\
\hline $\begin{array}{l}\text { Total number after exclusion } \\
\text { of duplicate search results } \\
\text { across all keywords }\end{array}$ & \multicolumn{8}{|c|}{30} \\
\hline
\end{tabular}

KW1: tax compliance; KW2: tax perception; KW3: tax behavioural insights; KW4: receipt lottery; KW5: tax lottery; KW6: tax amnesty; KW7: tax field experiment; KW8: tax reminder.

Source: Own processing. 
M. MÜLLER: Pregled kako su bihevioralna saznanja primijenjena na poreznu politiku i eksperimente u Europskoj uniji EKONOMSKI PREGLED, 72 (6) 799-825 (2021)

\section{IMPLEMENTATIONS OF TAX-RELATED BEHAVIOURAL INSIGHTS IN THE EUROPEAN UNION}

\subsection{Receipt-Based Tax Lotteries}

In order to reduce tax evasion and increase VAT compliance, several EU countries have introduced fiscal receipt lotteries that are inspired by the insights of behavioural economics that an "individual over-weighs small probabilities" (Lourenço et al., 2016, pp. 28-30). These lotteries are based on the mechanism of random awards to those who help tax authorities increase the issuance of receipts and eliminate the shadow economy.

These lottery mechanisms have been implemented in Malta (1997), Slovakia (2013), Croatia (2013), Portugal (2014), Romania (2015), Bulgaria (2015), Poland (2015), Slovenia (2016), Greece (2017), Lithuania (2017) and the Czech Republic (2017). Latvia also recently adopted a law for a receipt lottery (Latvijas Republikas Saeima 2018). A one-year lottery in Hungary was organized in 2009 that had its own specific participation conditions. Due to low participation, this initiative was ineffective (Lourenço et al., 2016, p. 32).

Some of the lottery campaigns are also supported by slogans that try to apply framing or an emphasis on social norms to influence individuals to take part in the lottery. This behavioural insight was employed as a special prize competition by the Croatian Tax Administration that was aimed at encouraging foreigners to ask for receipts (Lourenço et al., 2016, pp. 28-29). As part of the information campaign, this competition was accompanied by messages using framing and an emphasis on social norms: "Every receipt you take is an assurance of a more organized society and a more secure future. Call us at our toll-free number and report any fiscalization subject which does not respect the rules, in contrast to a large majority of others" (Lourenço et al., 2016, p. 29).

In general, there are no detailed evaluations on the effect of receipt lotteries. Several authors point to the lack of evidence, even in the countries that introduced lotteries several years ago like Malta or Portugal (Ungureanu \& Dascălu, 2015, Gábík \& Strížencová, 2014). Most of the available information relates to the fact that the increased tax revenue is higher than the cost of the lottery itself. Nevertheless, this data often relates to the first year after the lottery was introduced. The projects are considered successful, yet the impact on tax revenue is modest. For example, the Slovak Institute for Financial Policy estimates the impact of the Slovak lottery on VAT collection as being approximately 8.2 million EUR per year. Auditors of the Supreme Audit Office of the Slovak Republic consider this estimate optimistic but maintain a conservative view that a lottery can have a posi- 
tive, if immeasurable effect on VAT revenue (Supreme Audit Office of the Slovak Republic, 2018).

It is tricky to evaluate the actual impact of a lotteries as there are several factors that may influence tax collection. In this context, the number of registered receipts or participants are measured more often than revenue and compliance (Awasthi \& Engelschalk, 2018, p. 35). Furthermore, participation in the lotteries tends to decline. There is evidence for a decrease in participants from Slovakia and the Czech Republic. The statistical report on the number of players in the Slovak national receipt lottery is not regular. Nevertheless, there is data from the first year of the lottery published by the Institute for Financial Policy. In the first round of the lottery (September 2013), more than 230,000 participants registered receipts, yet by the eighth round (January 2014) this had dropped to less than 130,000 participants (Gábík \& Strížencová, 2014, p. 2). According to the Czech Ministry of Finance, there were 477,952 participants in the receipt lottery in November 2017, and 352,023 participants in October 2018 (Žurovec, 2017, 2018).

The task of the tax authorities is to target specific sectors with the highest probability of tax evasion (Fooken et al., 2015, p. 22). Nevertheless, regular participants, those who register the most receipts, have a limited scope to register receipts from business-to-consumer-transactions. If the largest share of receipts is issued, for example, by supermarket chains (in general are not connected with tax evasion), the goal of increasing tax compliance is not met. The shadow economy often relates to situations where the customer is willing to pay cash without an invoice to receive a cheaper service (Awasthi \& Engelschalk, 2018, p. 35, see Iacob, 2015 , for the case from Romania). These tendencies point to the fact that although lotteries are based on a simple idea and their implementation is not significantly challenging or expensive, it is much more complicated to design a lottery to meet its desired goals (Fooken et al., 2015, p. 3).

Although several governments point to the educational aim of receipt lotteries, this goal is not related to the inner value of tax morale. The main problem is related to crowding out the effect of voluntary requests for invoices (see Fabbri, Hemels, 2013, p. 18, Fabbri, 2015, p. 14). In this context, Fabbri and Wilks (2016, pp. 26-38), through a survey in Portugal, have tried to point out that tax lotteries crowd-out the willingness of educated individuals, who can be considered tax moral leaders, to engage in third-party tax enforcement. The preliminary evidence from their survey indicates that there are people willing to act as voluntary thirdparty tax enforcers, but they are not willing to continue after a lottery has been introduced. Their study highlights the fact that the crowding-out effect is positively associated with the level of education. Fabbri and Wilks (2016) conclude that this may negatively affect the general transmission of "tax morale" and can lead to possible welfare losses in the future. Moreover, a study by Wilks, Cruz, 
and Sousa (2019) examines the reasons for Portuguese citizens to request a receipt. The results of an online survey and a qualitative study showed that winning the lottery is not the main reason to request an invoice. The reason for cooperating with the tax authorities lies in the benefits that citizens receive, such as justice and good governance.

Another ethical question concerns the issue of gambling. It is argued within this discussion that individuals are not motivated to gamble, as lottery participants do not have a stake at risk. Based on the definition of gambling and the legal framework of receipt lotteries, it is not possible to consider such lotteries as gambling (Fooken et al., 2015, p. 21). However, as the example of Slovakia shows, there are so-called "professional" players who register the most receipts (Fooken et al., 2015, p. 15). Although there are no financial losses and the game is not gambling, the question is whether the behaviour of these "professional" players can be associated with an addiction. Another empirical question might relate to what percentage of participants in a receipt lottery also play real gambling lotteries. Moreover, in the case of Malta, lottery is connected not only with opportunity costs but also participation costs; receipts must be sent in a physical format. Furthermore, in the design of such a lottery, it is difficult to ensure fairness and transparency, as the National Audit Office of Malta declared (NAO 2017, pp. 114-115). Physical receipts must also be sent in the recent Croatian lottery (Ministarstvo Financija 2018).

\subsection{Educational Activities and Changing Tax Perception}

Ministries of finance from several countries in the European Union are making an effort to increase tax compliance through educational processes. In most cases, educational activities themselves are not related to the application of psychology and behavioural science. However, there are educational programs aimed at increasing tax compliance that are directly inspired by these scientific findings, or at least the application of behavioural insights is argued for in reports published by the European Commission. The most commonly used behavioural findings are those relating to framing or behavioural levers such as reciprocity, fairness, salience, or an emphasis on social norms (Lourenço et al., 2016, p. 28). Practically, this means that education is not solely based on the transmission of information and rational argumentation, but as targeted stimuli to trigger an emotional response. Another option is to use elements of gamification, a method that is inspired by cognitive psychology or neuroscience.

The Estonian educational initiatives are based on tax compliance surveys. A survey by Lillemets (2009) highlights the fact that $26 \%$ of respondents were not 
familiar with the services provided by the state. The author concluded that tax policy, apart from other activities, must be based on an attempt to increase tax morale. Nine Estonian cities took part in an information campaign in 2010 that relayed the message: "Unpaid taxes will leave a mark. You like motorways in order, ambulances, efficient work of rescue workers and the police. So do we." The second part of the campaign, carried out in 2011, focused on communicating to citizens what tax revenues bring to society by emphasizing the major problems of Estonian cities (Eurofound, 2013). Although the campaign was considered successful, as reported by the survey, the European Observatory of Working Life warns that measuring the impact of a campaign on tax behaviour is difficult since any observed change can be the result of numerous factors (Eurofound, 2013). Similar to other European countries, Estonia has recently placed an emphasis on electronic services to simplify tax returns and reduce the administrative burden of taxpayers. Future tax policies are shaped by policymakers and IT experts. A "SmartEST Taxation" conference was held in 2017 (Tax and Customs Board, 2017). Digitization is an important tool for improving tax administration. It can lead to the strengthening of public trust, and therefore to an increase in tax morale (Gangl \& Torgler, 2017).

The Austrian Federal Ministry of Finance is also trying to change the perceived fairness of the tax system in order to increase tax compliance. To achieve this goal a series of educational activities were introduced. One such project was the "Tax/Customs Education" program (2012) that informed young people and students as to how taxpayer money is used. Behavioural insights have been employed in these educational materials and tools, especially those that help increase reciprocity and a sense of fairness. Training was also done through classroom activities involving tax and custom officers (Lourenço et al., 2016, p. 28). Other European countries also focus on education to increase tax compliance of future generations. In the United Kingdom, HM Resource \& Customs introduced educational materials and a video that teaches young people how taxes work (HMRC, 2018).

Educational activities related to tax are currently centralized in a single learning portal for young Europeans known as “TAXED", created as part of a project led by the European Parliament and the European Commission (Directorate General for Taxation and Customs) with the cooperation of national administrations. The site provides animated videos, lessons, e-learning materials, and games related to tax education. Some of these materials evoke a direct emotional response. The video "How do I build a better future" shows, for example, what schools and sport centres would look like "without taxes" and "with taxes". There is also a game called TAXLANDIA where players decide the taxation level and allocate the budget. Players must respond to major social, environmental, and infrastructure related events, and decide how to invest in public services (TAXEDU, 2019). 


\subsection{Simplifying Tax Returns and Promoting Online Tax Returns}

Many countries in the European Union try to simplify tax returns by introducing pre-populated tax forms and electronic tax returns. Some of these countries use behavioural insights to influence taxpayers to use these services and to provide the right information. The FinanzOnline platform of the Austrian Ministry of Finance is an example. In promoting this service, an emphasis is placed on simplifying administrative burdens, fast and reliable access ("one-click link to the Austrian tax administration"), and framing the quality of services provided ("portal won an international eGovernment award" or "96\% users consider the services very good"). The launch of a mobile application led to the first significant increase in users from 106,754 in 2013 to 176,721 in 2014 (Lourenço et al., 2016, p. 29). At present, more than 4.7 million people use FinanzOnline. In addition, since 2003 , administrative costs have been reduced by approximately 650 million euros (FinanzOnline, 2018).

The electronic tax declaration and its pre-populated form are also used by other countries of the European Union, such as Spain, Hungary, Estonia, and France (Lourenço et al., 2016, p. 29, National Tax and Customs Administration, 2017, Tax and Customs Board, 2018).

In the context of using behavioural insights to motivate taxpayers to use electronic tax returns, the French government sent messages in 2014 to internet users based on behavioural levers such as loss aversion, salience, or an emphasis on social norms to influence them to make online tax declarations (Lourenço et al., 2016, p. 29). Taxpayer emotions are also targeted through an online tax return portal. The site shows several stories in the form of a photograph and description. The text "Gill has busy days, he filled in his tax return online this morning" is accompanied by a photo of a man who is enjoying his free time and having a barbecue with his friends (Déclaration en ligne, 2019).

Researchers in the United Kingdom experimentally examined the effect of pre-populated tax forms on tax compliance and determined that correct pre-population has no effect on compliance. Moreover incorrect pre-population even reduces compliance (Fonseca \& Grimshaw, 2015). It seems that further research and a thorough investigation into the effect of pre-populated forms is needed.

\subsection{Curative Measures and Tax Amnesties}

In addition to measures that seek to prevent noncompliant behaviour, there are measures that have a curative character. These measures relate to situations 
where noncompliant behaviour has already taken place. In this respect, tax amnesties are a common measure for tax policies. The main objective of a tax amnesty, from the government's point of view, is to quickly collect taxes from undeclared incomes, as well as to reduce the administrative cost of detecting and collecting unpaid taxes. Apart from the economic aspect, a tax amnesty can be viewed in the context of psychology. In this respect, it can be mentioned that a tax amnesty gives taxpayers a chance to start a new tax compliance history. A tax amnesty lowers taxpayers' guilt and fear, and so gives them the opportunity to remedy their earlier illegal behaviour. Participation in the amnesty becomes a strategy to overcome an existing evasion strategy that serves to remove uncertainty (Yaniv, 1999, p. 755). Various models can serve to capture this fact, and in the context of behavioural economics, the model of Alm and Beck (1990) using prospect theory can be mentioned (Yaniv, 1999, p. 755).

Within the European Union, a number of member states have declared various tax amnesty programs: Austria (1982, 1993), Belgium (1984, 2004, 2005), Cyprus (2017), Denmark (2013), Finland (1982, 1984), France (1982, 1986), Germany (2004-2005), Greece (2004-2005, 2010), Hungary (2008, 2013), Ireland (1988, 1993), Italy (1982, 1984, 2002, 2009), Latvia (2012), Lithuania (2019), Luxembourg (2016-2017), Malta (2011), the Netherlands (1934, 1940, 1945, 1955, 2009, 2010, 2013, 2014, 2015), Portugal (1981, 1982, 1986, 1988, 2005, 2010), and Spain (1977, 2012), United Kingdom (2009) (Devroe, 2005, Traversa, 2010, Gencs, 2011, Reumert, 2012, OECD, 2015, Estagerie \& Aldariz, 2016, Gorringe, 2017, Orbitax, 2018).

Although tax amnesties are popular as an instrument aimed at raising tax revenue, experimental research within tax psychology provides findings related to its negative effects on tax compliance (Nar, 2015, p. 583). The European Commission also draws attention to challenging aspects of tax amnesties and potential counterproductive effects. The authors of this document point out that the effectiveness of a tax amnesty is subject to several conditions. Firstly, the tax amnesty should be one-off and should not give rise to expectations in the future. Secondly, a real and credible threat of detection and punishment should exist. However, these conditions are seldom fulfilled and there are often additional issues. One problem is vertical inequality - dishonest taxpayers are favoured over honest taxpayers. This has the effect of reducing perceived fairness and can lead to a reduction in tax compliance with honest taxpayers. In addition, declaring a tax amnesty often raises expectations of future tax amnesty programs. The effects of a tax amnesty are often overestimated, and the subsequent analysis does not include the impact of the program on tax morale (Jensen \& Wöhlbier, 2012, p. 31). The negative consequences of tax amnesties are also shown by analyses from countries that have not introduced tax amnesties. The main reasons are the effect on tax compliance and tax morale (Žunić Kovačević, Gadžo, 2017). 
Analyses of the impact of tax amnesties provoke discussions. In the European context, the effects of a Spanish tax amnesty is discussed. López-Laborda and Rodrigo (2003) evaluate the impact of amnesty measures in 1991 on Spanish individual income tax compliance. The results of their analysis show that amnesty had no effect on tax collection in either the short or long term. Rather, positive impacts can be seen in the legislative and administrative measures that were part of tax reforms. Moreover, as stated by Sánches Huete (2013, p. 116) in the context of the Spanish tax amnesty, discrimination based on favouring non-compliant operators cannot be avoided. This violates the principle of constitutional equality. There is a sceptical view of amnesties in other countries as well. Analysis of the impact of tax amnesties, including data from Latvia, points to a small effect and collecting a relatively small revenue, while there is a potential reduction in tax compliance (Rymanov, 2017, pp. 123-124).

\section{FIELD EXPERIMENTS AND BEHAVIOURALLY INFORMED LETTERS IN THE EUROPEAN UNION}

Several field experiments were conducted in the United Kingdom where behavioural approaches have gained government support. This is being developed by the Behavioural Insights Team, a global social purpose company operating around the world (BIT, 2019). The Behavioural Insights Team developed frameworks such as MINDSPACE (Dolan et al., 2010) and EAST (Service et al., 2014) which can be used by policymakers as checklists of the main influences on behaviour. One of the field experiments was carried out in 2001. Five different letters with appeals (advice offer, appeal to citizenship, increased audit information, audit/penalties information, preselected audit information) were used to examine their effect on tax compliance. The results show that all letters increased compliance (Hasseldine et al., 2007, pp. 188, 191). Hallsworth et al. (2017) tested the effect of social norms on tax compliance in field experiments. Reminder letters with framing statements were sent in 2011 and 2012. The results show that payment rates for overdue taxes increased. A summary of randomized control trials that tested the use of behavioural insights in practice was published by the Behavioural Insights Team and the UK Cabinet Office in 2012. The document describes the positive effects of different insights such as social norms, highlighting key messages, using salient images, and varying the tone of letters on tax compliance (BIT, 2012).

The Irish Office of the Revenue Commissioners focuses on understanding taxpayer compliance behaviour. A randomized trial aimed at increasing renewals of a publican's licence was part of this initiative. Behaviourally informed letters 
included a social normative message that 9 out of 10 publicans renew a licence on time were sent to holders of a publican's licence in 2011. Renewal rates increased by 6 percent in the case of the test group (Purcell, 2016, pp. 30-31). Other research projects were carried out in 2014 and 2015. Apart from a regular reminder letter (control group), two types of letters were sent to late taxpayers. These letters included a statement that a third party informed the tax authorities that their business was in operation. In addition, one of these letters was written in a simplified form. The results show a significant increase in filling compliance in the case of simplified letters that included third party information - an increase of 17 percent in comparison with a standard reminder letter (Purcell, 2016, pp. 34-35).

Researchers from the Office of the Revenue Commissioners and the Irish Government Economic \& Evaluation Service published a summary of applying behavioural science within the Irish tax administration in 2017. The document summarizes the results of 20 randomized control trials carried out over a period of 6 years. The meta-analysis of the research results reveals that behavioural insights do affect taxpayer compliance. The most successful tool was deterrence, which had an 8 percent effect on improvement in the targeted behaviour. Personalization increased compliance by 3 percent and the combination of simplification and salience by 3.3 percent. The appeal to social norms had, however, no or a statistically insignificant effect on tax compliance. The results related to social norms are in contradiction with the result in the UK. This fact indicates different responses depend on the country and the local conditions (Kennedy et al., 2017, pp. 3, 27).

In Denmark, a field experiment with more than 40,000 taxpayers was conducted in 2007-2008. Researchers examined the impact of a written notification informing of either a 50 percent or 100 percent probability of an audit. The threat of audit had a significant effect on reported income. Moreover, the effect of the 100 percent threat was larger than the 50 percent threat. It is important to note that the quantitative magnitudes of the effects were modes in comparison with the effects of an actual audit. The authors explain this fact that actual audits increase the probability of detection, while a notification only has an impact on increasing the probability of an audit but no longer affects the perceived probability of detection (Kleven at al., 2011, pp. 686-689).

In Finland, researchers used an increase in VAT rates for hairdressers in 2012 to conducted a field experiment. A range of small businesses, including a group of hairdressers that were the subject of the tax reform, were sent two types of letters with a statement about the high or low probability of an audit. Research results have shown that letters indicating a higher probability of an audit significantly increased declared turnover. However, this fact was only related to the hairdressers, whose business was directly affected by the new tax reform (Harju, Kosonen \& Ropponen, 2013). Another study based on a field experiment by Kosonen and 
Ropponen (2015) revealed that business made unintentional mistakes in their VAT reports after the tax reform. These mistakes are significantly reduced when businesses are informed of the tax rules. In addition, entrepreneurs are aware of the higher probability that their tax evasion behaviour might be detected.

In Bavaria, Germany, approximately 40,000 people were sent letters to increase payment of the church tax in 2012. Several different techniques were used (tax simplification, assertions about different auditing probabilities, social and monetary rewards, moral appeal) and their effect on tax compliance was examined. Statements on the zero probability of an audit (the status quo) only had a limited effect on compliance. Tax simplification and deterrence had a strong impact on compliance. The provision of a reward had a different effect. Baseline evaders reduced their compliance and baseline donors further increased their payments (Dwenger et al., 2014, pp. 2-3).

In a field experiment that was carried out in Slovenia in 2014, researchers focused on tax compliance within 142 small businesses. The businesses in the first group received a letter based on moral appeals and emphasized the importance of paying taxes. The second group of businesses was visited by mobile units of Slovenian tax authorities and received the same letter in person. The control group was not tested (Doerrenberg \& Schmitz, 2017, pp. 47-48). The results show that an average increase in the tax base was greater in the test groups relative to the control group. Moreover, the tax base increased more in the case of the visit group (20,28 percent) than in the letter group $(12,68$ percent), but the difference between the groups was not statistically significant. The disadvantage of the study was the low research sample. However, the authors believe that the results could indicate that personal interaction can help improve tax compliance (Doerrenberg \& Schmitz, 2017, pp. 50-52).

In Austria, the effect of behaviourally informed letters of compliance was tested in 2005. More than 50,000 people with a high probability of not paying a TV license fee (an obligatory fee as in the case of taxes) were sent letters that had a significant effect. The number of participants registering for the license increased most significantly in case of legal threat. Moral appeal and letters containing information about other fee-payers did not have an additional effective influence on compliance (Fellner, Sausgruber \& Traxler, 2013, p. 634).

Additional field experiments on the impact of supervision on tax compliance in Austria were carried out by Gangl et al. (2014). 93 of the 1721 businesses in East-Styria were randomly selected and included in a group that was the subject of supervision. This supervision consisted of an initial visit and a continuous audit during the first year. The research focused on one (the best measurable) aspect of tax compliance, namely on timely payments. Despite their expectations, the results indicate that supervision reduces tax compliance (Gangl et al., 2014, pp. 378-382). 
Reminders were sent to Belgian taxpayers in 2015-2016. Researchers used a simplified letter. They sent either the simplified letter with a social message, or the simplified letter with a deterrence message. The results of the field experiment revealed no effect from the social messages. Simplification had a large impact on tax compliance and this effect was doubled by the deterrence message (Imbert et al., 2017).

Researchers in Italy estimated the influence of social pressure on tax compliance with shopkeepers by asking for receipts in bakeries in field experiments. The results of the study show that traders increased their receipts by 17.4 percent in the short term. This result was significant at the 10 percent level (Battiston \& Gamba, 2016 , p. 84). In addition to behaviourally informed letters, the probability of an audit was presented through the media.

A study in Italy (Battiston et al., 2018) showed the effect of public media on VAT tax compliance. However, these studies did not work with the use of behavioural knowledge to form media warnings. These strategies can thus be considered a kind of deterrence.

Researchers in the Netherlands tested the long-term impact of a tax training program on compliance for first-time entrepreneurs in a field experiment. The results of the research indicate that training had a modest but positive effect on tax compliant behaviour. The authors note that these findings suggest that, rather than deterrence, the service-oriented approach might be an effective tool. Moreover, there was a significant effect on bookkeeping and meeting administrative requirements. Small positive effects have been noted even two years after training, which could indicate a long-term effect of this initiative. However, further research is necessary to confirm these results. The authors believe that similar training could also improve perception of the tax authorities (Nagel et al., 2019, pp. 261-283).

Field experiments are used in countries that are not EU members, but part of the Schengen area such as Switzerland and Norway, to identify the impact on tax compliance. A field experiment investigating the influence of moral persuasion on timely payments and filling out tax forms was carried out in Switzerland in 2001. A significant effect on the behaviour of taxpayers was not observed (Torgler, 2004, 2013). Another field experiment by Koessler et al. (2019) examines the effect of taxpayer promises to pay their taxes on time. The results show that people with high scores on tax morale or with a history of compliance are more likely to make a promise. However, only the option to make a promise does not lead to changes in tax compliance.

In Norway, a field experiment that focused on efforts to increase tax compliance with Norwegian tax residents that have income from foreign countries. This group is more likely to have misreported their income in previous years. The ex- 
periment was conducted to increase declared income in tax returns for 2012. Two types of letters were sent, one neutral and one with a moral appeal. The results show that both types of letters significantly increased self-reported income. The increase was two times higher in the case of the moral appeal (Bott et al., 2014).

\section{DISCUSSION}

Although nudges have gained considerable popularity in recent years, empirical evidence shows that for many reasons it can fail (Sunstein, 2017). The fact that these nudges are the most commented on and the most widespread policies does not mean that they are the most effective tools. As Lowenstein and Chater (2017, p. 26) point out, there is a wide range of hybrid policy actions that are based on a combination of behavioural and economic components that may have better potential. It is important to share data and knowledge and regularly evaluate the effectiveness of behaviourally based policies and compare them to other policy tools to overcome recent problems (Benartzi et al., 2017, p. 1052). The European Economic and Social Committee also recognizes the challenging aspects of nudging, draws attention to its possible risks and limitations, and makes some recommendations regarding the need to investigate the different effects of nudges, or the need to develop monitoring and evaluation procedures for these policies (OJ C75, 2017, pp. 29-32).

The results of empirical studies that examine not only the short-term effects of behaviourally informed letters and informational interventions but also its long-term effects, demonstrate that the effects of these nudges are substantially lower and potentially insignificant over the long term. Although different letters have had a different nudge effect, the long-term learning effects are not different (Manoli \& Turner, 2014). As was shown in the field experiment in Austria (Gangl et al., 2014), supervision may in some cases reduce tax compliance. An analysis of the backfiring effect of auditing on tax compliance was carried out by Mendoza, Wielhouwer and Kirchler (2017, p. 284) in their study. The results of various tests, based on data from several countries from 2003-2014, indicate that compliance increases until a certain level of auditing. Compliance decreases beyond this level. It seems that tax compliance increases with trust in government and the backfiring effect may be related to the fact that excessive audits create obstacles for taxpayers to comply voluntarily. The results of the study by Williams and Franić (2016, p. 99) on participation in undeclared work in Bulgaria shows that the level of tax morale is more important than the perceived level of penalties and risk of detection. Participation in undeclared work and tax evasion may be reduced by policy 
interventions that seek to improve tax morale. Tax morale as a factor underlying the demand for and supply of undeclared goods and services was also confirmed in Poland (Franić, 2019).

Late tax returns (field experiment by Gangl et al., 2014) may not mean a reluctance to pay tax, but rather taxpayers could be stressed out because of tax control and they wish to gain additional time to put everything in order. They simply prefer to fill in the tax return later. Their main reason could be fear of an audit. It appears that tax compliance is mostly increased due to fear in taxpayers. This fear is not related, however, to a general increase in tax morale. We may ask whether, for example, the statement " 9 out of 10 taxpayers pay their taxes on time" is really related to social norms, and if it is a matter of compliance with this norm and awareness of the taxes for society, or if is also a way of deterrence. At the same time, this statement says: "we have an overview of all taxpayers, it is very likely that we will detect your tax evasion". As the review study by Horodnic (2018, p. 878) demonstrates, deterrence might even lead to lower tax morale with negative effects on tax compliance. The results of the studies indicate that to increase tax morale, trust in public authorities and perceived effectiveness of government spending is important.

Backfiring can also be based on the methodological drawbacks of nudges as we have seen in the case of a pre-populated tax form that reduced compliance (Fonseca \& Grimshaw, 2015, 2017). As Kuehnhanss has pointed out, there is evidence that if the default is set too low the backfiring effect can emerge. More importantly, it is not clear what really influences taxpayer behaviour. The reason why a specific tool may work in some cases but not others is not fully understood (Kuehnhanss, 2018, p. 13; for several factors that influence taxpayer behaviour see Lunn, 2014, p. 45). Therefore our knowledge is still limited. Current conclusions about tax compliance are drawn from isolated studies concerning certain types of taxes and taxpayers, in specific situations, and in different geographical contexts (Hallsworth, 2014, p. 674). Although many of the studies point to different effects, precise causal mechanisms are not known and it is very difficult to estimate the impacts of these nudges and other behaviourally informed policies (Lunn, 2014, pp. 61-62).

In addition, it should be noted that nudges and behavioural insights concern the ethical problems of libertarian paternalism. Reiss (2013, p. 294) notes that most philosophers, commenting on the proposal of libertarian paternalism, advocate that libertarian paternalism is not very successful in keeping its promise - that it will not restrict freedom of decision. Hausman and Welch (2010, p. 130) consider that these approaches can jeopardize the control that individuals have over their own choices and the ability to consider the alternatives. This poses a threat to freedom. They believe that the ideal way governments should influence their citizens is rational persuasion. Reiss (2013, p. 296) agrees with, and also sees, the threat of pa- 
ternalistic policies, but points out that this critique does not correspond to the main argument of Thaler and Sunstein (2008), which is that people are characterized by bounded rationality, willpower, and selfishness. If we cannot refute this premise, Reiss points out, rational persuasion will still be considered less attractive.

In the case of taxes, it seems to be yet another issue. Taxpayers have two options, to pay taxes properly, or to avoid paying taxes - which is a violation of the law. Violation of the law is therefore a socially unacceptable alternative that can be suppressed by means of manipulation. This change in human behaviour is unrelated, however, to changes in the level of their knowledge or their moral character. As the review of field experiments indicates, the appeal to social norms is not one of the most efficient tools to have an impact on tax compliance. Deterrence has always been more effective. In addition, many behavioural tools can have short-term effects. Even in the case of receipt lotteries, there is the risk that the consequences of this initiative may negatively affect the generational transmission of the "tax morale" and lead to possible welfare losses in the future. Additionally, there are no records of whether these lotteries have an impact on gambling behaviour, since most of the receipts are registered by so-called professional players. Although it is argued that no costs are associated with these lotteries, and there is no hazard involved, it is possible to identify certain costs, especially when the lottery is not carried out online. Tax amnesties are also problematic in the context of tax morale, favouring those who have not paid their taxes in the past.

Education can be an important tool for increasing tax compliance from a long-term perspective. Although education and rational persuasion may not be effective, as we have mentioned above, it is a method that supports the gradual creation of tax morale and responsible taxpayers who are aware of the importance of taxes. Even within educational processes it is possible to use a range of behavioural insights. However, if the taxes are not used in ways that governments declare and taxpayers see their taxes are used inefficiently, this may cause distrust in both the educational system and in the government, especially if emotional manipulation is used within the learning processes. Education should not be replaced by manipulations and nudges that have significant effects in the short term, especially when the long-term effects remain unclear. In addition, surveys among university students indicate that tax education has a positive impact on tax morale, despite the varying focus of these courses (Goksu \& Sahpaz, 2015, p. 230).

\section{CONCLUSION}

The member states of the European Union are aware of the seriousness and complexity of tax evasion. In order to increase tax compliance they attempt to 
implement current trends in behavioural economics. This review focused on two groups of activities - broadly implemented behavioural insights, such as the introduction of receipt lotteries, behaviourally inspired educational activities, simplifying tax returns, and behavioural field experiments that investigate the impact of various behavioural levers on tax compliance.

Although governments consider receipt lotteries a success, based on the insight that people overestimate low probabilities, there is a lack of analyses that confirm the effects of these initiatives. Moreover, measurements of the impact of receipt lotteries have been challenging. The countries of the European Union are also active in creating platforms for tax education. An emphasis on the importance of taxes for the welfare of society is significant. At present, there are websites that aim to provide important information about taxes and their role in society. For this purpose, video tutorials have been developed, as well as games that support tax awareness through the principles of gamification. Behavioural insights are also used to promote simplified tax return forms. Pre-populated tax forms are also one of many tools. However, this tool can have a backfiring effect in cases when the wrong data has been collected by tax authorities.

Many field experiments have been conducted in the European Union. Most of the research is based on examining the impact of behaviourally informed reminders on tax compliance. Letters containing statements based on behavioural insights increase tax compliance more than standard letters sent to a control group. The research results show that field experiments are successful - the increased tax revenues far exceed the costs of the research. Deterrence has the most significant effect, more so than a combination of several behavioural insights. Although deterrence increases tax compliance, it is uncertain whether it has any effect on tax morale. It seems that tax compliance will only increase to certain levels of auditing. Yet it is unclear what effect these instruments will have over the long term. In addition, these conclusions cannot be generalized across the EU, as studies are carried out in different countries with different national and cultural contexts. From the long-term perspective, tax education will play an important role in efforts to increase tax morale.

Acknowledgement - This article was supported by the Ministry of Education, Youth and Sports of the Czech Republic within the project IGA_FF_2019_009 "Current research, technological and philosophical trends and their impact on selected areas of economy and management" of Palacký University Olomouc. 
M. MÜLLER: Pregled kako su bihevioralna saznanja primijenjena na poreznu politiku i eksperimente u Europskoj uniji EKONOMSKI PREGLED, 72 (6) 799-825 (2021)

\section{REFERENCES}

1. Ahčin, J. (2018). Pravila o prirejanju nagradne igre v letu 2019 z imenom "Vklopi razum, zahtevaj račun!“. Finančna uprava Republike Slovenije, available at: http://www.fu.gov.si/fileadmin/Internet/O_financni_upravi/Nagradne_igre_in_natecaji/Nagradna_igra/Pravila.pdf

2. Alm, J., \& Beck, W. (1990). Tax amnesties and tax revenues. Public Finance Review, 18(4), 371-394.

3. Awasthi, R., \& Engelschalk, M. (2018). Taxation and the shadow economy: How the tax system can stimulate and enforce the formalization of business activities. Policy research Working paper 8391. World Bank Group, Governance Global Practice, available at: http://documents.worldbank.org/curated/ en/497071522428886160/pdf/WPS8391.pdf

4. Battiston, P., \& Gamba. S. (2016). The impact of social pressure on tax compliance: A field experiment. International Review of Law and Economics, 46, 78-85, https://doi.org/10.1016/j.irle.2016.03.001.

5. Battiston, P., Duncan, D., Gamba, S., \& Santoro, A. (2018). Audit publicity and tax compliance: A natural experiment. The Scandinavian Journal of Economics. First published August 2018, https://doi.org/10.1111/sjoe.12330.

6. Benartzi, S., Beshears, J., Milkman, K. L, Sunstein, C. R., Thaler, R. H, Shankar, M., Tucker-Ray, W., Congdon, W. J., \& Galing, S. (2017). Should governments invest more in nudging? Psychosociological Science, 28(8), 1041-1055, https://doi.org/10.1177/0956797617702501.

7. BIT. (2012). Applying behavioural insights to reduce fraud, error and debt. Behavioural Insights Team and UK Cabinet Office, available at: https://www. gov.uk/government/publications/fraud-error-and-debt-behavioural-insightsteam-paper

8. BIT. (2019). About us. The Behavioural Insights Team, https://www.bi.team/ about-us/

9. Bott, K., Cappelen, A. W., Sørensen, E. Ø., \& Tungodden, B. (2014). You've got mail: A randomised field experiment on tax evasion. Department of Economics, Norwegian School of Economics, Discussion Paper 26/2014, available at: https://eml.berkeley.edu// saez/course/bottetal14.pdf

10. Congdon, W. J., Kling, J. R., \& Mullainathan, S. (2011). Policy and Choice: Public Finance through the Lens of Behavioral Economics. Washington (DC): Brookings Institution Press.

11. Déclaration en ligne. (2019). Déclarer en ligne. Ministère de l'Action et des Comptes publics, available at: https://www.impots.gouv.fr/portail/www2/minisite/declaration/je-declare-mes-revenus-en-ligne.html 
12. Devroe, W. (2005). Tax amnesty and community law. Maastricht Journal of European and Comparative Law, 12(3), 217-226.

13. Doerrenberg, P., \& Schmitz, J. (2017). Tax Compliance and Information Provision - A Field Experiment with Small Firms. Journal of Behavioral Economics for Policy, 1(1), 47-54.

14. Dolan, P., Hallsworth, M., Halpern, D., King, D., \& Vlaev, I. (2010). MINDSPACE: Influencing Behaviour Through Public Policy. Institute for Government and Cabinet Office, available at: https://www.instituteforgovernment. org.uk/sites/default/files/publications/MINDSPACE.pdf

15. Dwenger, N., Kleven, H., Rasul, I., \& Rincke, J. (2014). Extrinsic and Intrinsic Motivations for Tax Compliance: Evidence from a Field Experiment in Germany. Vereins für Socialpolitik 2014: Evidenzbasierte Wirtschaftspolitik, available at: https://www.econstor.eu/handle/10419/100389

16. Eurofound. (2013). Information Campaign on Tax Compliance, Estonia. European Foundation for the Improvement of Living and Working Conditions, available at: https://www.eurofound.europa.eu/data/tackling-undeclared-work-ineurope/database/information-campaign-on-tax-compliance-estonia

17. Estagerie, P. J., \& Aldariz, X. M. (2016). Luxembourg: Luxembourg tax amnesty - an unmissable opportunity. ITR: International Tax Review, available at: https://www.internationaltaxreview.com/article/b1f7nctxg95w4z/luxembourg-luxembourg-tax-amnesty-an-unmissable-opportunity

18. Fabbri, M. (2015). Shaping tax norms through lotteries. International Review of Law and Economics, 44(2015), 8-15.

19. Fabbri, M., \& Hemels, S. (2013). "Do you want a receipt?" combating VAT and RST evasion with lottery tickets. INTERTAX, 41(8\&9), 430-443.

20. Fabbri, M., \& Wilks, D. C. (2016). Tax Lotteries: The Crowding-out of Tax Morale and Long-Run Welfare effects. Journal of Legal, Ethical and Regulatory Issues, 19(2), 26-38.

21. Fellner, G., Sausgruber, R., \& Traxler, C. (2013). Testing Enforcement Strategies in the Field: Threat, Moral Appeal and Social Information. Journal of the European Economic Association, 11(3), 634-660, https://doi.org/10.1111/ jeea.12013.

22. FinanzOnline. (2018). FinanzOnline (FON): Per Mausklick zur Finanzverwaltung. Bundesministerium Finanzen, available at: https://www.bmf.gv.at/ egovernment/fon/FON_Ueberblick.html

23. Fonseca, M., \& Grimshaw, S. (2015). Does Using Behavioural Prompts in Pre-Populated Tax Forms Affect Compliance? Results From an Artefactual Field Experiment With Real Taxpayers. Tax Administration Research Cen- 
tre, Discussion Paper, 015-15, https://tarc.exeter.ac.uk/media/universityofexeter/businessschool/documents/centres/tarc/publications/discussionpapers/ Fonseca_\&_Grimshaw_Sept15.pdf

24. Fonseca, M. A., \& Grimshaw, S. B. (2017). Do Behavioral Nudges in Prepopulated Tax Forms Affect Compliance? Experimental Evidence with Real Taxpayers. Journal of Public Policy \& Marketing, 36(2), 213-226, https://doi. org/10.1509/jppm.15.128

25. Fooken, J., Hemmelgarn, T., \& Herrmann, B. (2015). Improving VAT Compliance - Random Awards for Tax Compliance. Taxation papers, working paper n. 51-2014. Luxembourg: Office for Official Publications of the European Communities.

26. Franić, J. (2019). Repression, voluntary compliance and undeclared work in a transition setting: some evidence from Poland. Post-Communist Economies, DOI:10.1080/14631377.2019.1640984

27. Gábik, R., \& Strížencová, K. (2014). Bločková lotéria si na DPH zarobí štvornásobne Prvé výsledky fungovania bločkovej lotérie. Inštitút finančnej politiky, Ministerstvo financií SR, available at: https://www.finance.gov.sk/ sk/financie/institut-financnej-politiky/publikacie-ifp/komentare/8-blockovaloteria-si-dph-zarobi-stvornasobne-maj-2014.html

28. Gangl, K., \& Torgler, B. (2017). Fostering Tax Morale in the Digital Age: The Evidence-based Tax Administration. Tallinn, SmartEST Taxation Conference, available at: https://www.emta.ee/sites/default/files/contacts-aboutETCB/structure-tasks-strategy/conference/katharina_gangl_fostering_tax_ morale_in_the_digital_age._the_evidence-based_tax_administration.pdf

29. Gangl, K., Torgler, B., Kirchler, E., \& Hofmann, E. (2014). Effects of Supervision on Tax Compliance: Evidence from a Field Experiment in Austria. Economics Letters, 123(3), 378-382, https://doi.org/10.1016/j.econlet.2014.03.027.

30. Gencs, V. (2011). Tax Amnesty in Latvia. Gencs Valters Law Firm, available at: http://www.gencs.ee/news/view/78

31. Goksu, G. G., \& Sahpaza, K. I. (2015). Comparison of Tax Morale of Turkish and Spanish Higher Education Students: The Samples of Sakarya University and the University of Zaragoza. Procedia - Social and Behavioral Sciences, 186(2015), 222-230, https://doi.org/10.1016/j.sbspro.2015.04.027

32. Gorringe, J. (2017). Cyprus Opens New Tax Amnesty For Past Tax Dues. TAX-NEWS: Global tax news, available at: https://www.tax-news.com/news/ Cyprus_Opens_New_Tax_Amnesty_For_Past_Tax_Dues 74718.html

33. Hallsworth, M. (2014). The Use of Field Experiments to Increase Tax Compliance. Oxford Review of Economic Policy, 30(4), 658-679, https://doi.10.1093/ oxrep/gru034. 
34. Hallsworth, M., List, J. A., Metcalfe, R. D., \& Vlaev, I. (2017). The Behavioralist as Tax Collector: Using Natural Field Experiments to Enhance Tax Compliance. Journal of Public Economics, 148(2017), 14-31, https://doi. org/10.1016/j.jpubeco.2017.02.003.

35. Harju, J., Kosonen, T., \& Ropponen. O. (2013). Do Honest Hairdressers Get a Haircut? On Tax Rate and Tax Evasion. Government Institute for Economic Research (VATT), Working Paper, available at: http://www.tax.mpg.de/fileadmin/user_upload/Paper_Jarkko_Harju-_Tuomas_Kosonen_and_Olli_Ropponen2.pdf

36. Hasseldine, J., Hite, P., James, S., \& Toumi, M. (2007). Persuasive Communications: Tax Compliance Enforcement Strategies for Sole Proprietors. Contemporary Accounting Research, 24(1), 171-194, https://doi.org/10.1506/ P207-004L-4205-7NX0.

37. Hausman, D. M., \& Welch, B. (2010). Debate: To Nudge or not to Nudge. Journal of Political Philosophy, 18(1), 123-136, https://doi.org/10.1111/j.14679760.2009.00351.x.

38. HMRC. (2018). Junior Tax Facts. The official HM Resource \& Customs Facebook page, available at: https://www.facebook.com/HMRC/videos/junior-tax-facts-fun-and-interesting-video-about-tax/1938916086390280/

39. Horodnic, I. A. (2018). Tax morale and institutional theory: a systematic review. International Journal of Sociology and Social Policy, 38 (9/10), 868886, https://doi.org/10.1108/IJSSP-03-2018-0039.

40. Iacob, I. (2015). The Lottery of Fiscal Receipts. A Brief Analysis. International conference: Law between modernization and tradition. Implications for the legal, political, administrative and public order organization. Bucharest, 21-23 April 2015, https://heinonline.org/HOL/Page?collection=journals \&handle=hein.journals/cidstue2015\&id=1\&men_tab=srchresults

41. Imbert, C., De Neve, J-E., Luts, M., Spinnewijn, J., \& Tsankova, T. (2017). Behavioural Insights and Tax Compliance: Evidence from Large-Scale Field Experiments in Belgium. Philadelphia, NTA Conference (9 November, 2017), available at: https://www.ntanet.org/wp-content/uploads/proceedings/2017/ NTA2017-328.pdf

42. Jensen, J., \& Wöhlbier, F. (2012). Improving tax governance in EU Member States: Criteria for successful policies. European Commission, DirectorateGeneral for Economic and Financial Affairs, doi: 10.2765/23869.

43. Kennedy, S., O’Carroll, R., Shirran, M., \& Walsh, K. (2017). Applying Behavioural Science in Tax Administration - A Summary of Lessons Learned. Statistics \& Economic Research Branch of the Office of the Revenue Commissioners, the Irish Government Economic \& Evaluation Service, available 
at: https://www.revenue.ie/en/corporate/documents/research/applying-behavioural-science.pdf

44. Kleven, H. J., Knudsen, M. B., Kreiner, C. T., Pedersen, S, \& Saez, E. (2011). Unwilling or Unable to Cheat? Evidence from a Tax Audit Experiment in Denmark. Econometrica, 79(3), 651-692, https://doi.org/10.3982/ECTA9113.

45. Koessler, A.-K., Torgler, B., Feld, L. P., \& Frey, B. S. (2019). Commitment to pay taxes: Results from field and laboratory experiments. European Economic Review, 115, June 2019, 78-98, https://doi.org/10.1016/j.euroecorev.2019.02.006.

46. Kosonen, T., \& Ropponen, O. (2015). The Role of Information in Tax Compliance: Evidence From a Natural Field Experiment. Economics Letters, 129, 18-21, http://dx.doi.org/10.2139/ssrn.2334059.

47. Kirchler, E. (2009). The Economic Psychology of Tax Behaviour. Cambridge: Cambridge University Press.

48. Kuehnhanss, C. R. (2018). The Challenges of Behavioural Insights for Effective Policy Design, Policy and Society, https://doi.org/10.1080/14494035.201 8.1511188

49. Latvijas Republikas Saeima. (2018). Saeima adopts Law on Receipt Lottery. Latvijas Republikas Saeima, available at: http:/www.saeima.lv/en/news/ saeima-news/27365-saeima-adopts-law-on-receipt-lottery

50. Lillemets, K. (2009). Maksumoraal maksukäitumise kujundajana ja selle peamised isikupõhised mõjutegurid. Riigikogu Toimetised, 2009(20), 71-83. https:/rito.riigikogu.ee/wordpress/wp-content/uploads/2016/04/RiTo-20.pdf

51. Loewenstein, G., \& Chater, N. (2017). Putting Nudges in Perspective. Behavioural Public Policy, 1(1), 26-53, https://doi.org/10.1017/bpp.2016.7.

52. López-Laborda, J., \& Rodrigo, F. (2003). Tax Amnesties and Income Tax Compliance: The Case of Spain. Fiscal Studies, 24(1), 73-96.

53. Lourenço, S. J. Ciriolo, E., Almeida, S. R., \& Troussard, X. (2016). Behavioural insights applied to policy: European Report 2016. EUR 27726 EN, https://doi:10.2760/903938.

54. Lunn, P. (2014). Regulatory Policy and Behavioural Economics. OECD Publishing, available at: http://dx.doi.org/10.1787/9789264207851-en

55. Manoli, D. S., \& Turner, N. (2014). Nudges and Learning: Evidence from Informational Interventions for Low-Income Taxpayers. National Bureau of Economic Research, NBER Working Paper 20718, available at: https://www. nber.org/papers/w20718.pdf

56. Mendoza, J. P., Wielhouwer, J. L., \& Kirchler, E. (2017). The Backfiring Effect of Auditing on Tax Compliance. Journal of Economic Psychology, 62, 284-294, https://doi.org/10.1016/j.joep.2017.07.007. 
57. Ministarstvo Financija. (2018). Bez računa se neračuna. Ministarstvo Financija, Porezna Uprava, available at: https://www.porezna-uprava.hr/Stranice/ TraziRacuneUloviKune.aspx

58. Ministerstwo Finansow. (2017). Narodowa Loteria Paragonowa, Ministerstwo Finansow, available at: https:/www.mf.gov.pl/ministerstwo-finansow/ dzialalnosc/dzialalnosc-edukacyjna/projekty/-/asset_publisher/2IKb/content/narodowa-loteria-paragonowa-1/pop_up?_101_INSTANCE_2IKb_ viewMode=print

59. Nagel, H., Rosendahl Hubel, L., Van Praag M., \& Sjoerd, G. (2019). The Effect of a Tax Training Program on Tax Compliance and Business Outcomes of Starting Entrepreneurs: Evidence from a Field Experiment. Journal of Business Venturing, 34(2), 261-283, https://doi.org/10.1016/j.jbusvent.2018.10.006.

60. Nar, M. (2015). The Effects of Behavioral Economics on Tax Amnesty. International Journal of Economics and Financial Issues, 5(2), 580-589.

61. NAO. (2017). Annual Audit Report Public Accounts 2017. National Audit Office Malta, available at: https://parlament.mt/media/98723/02648.pdf

62. National Tax and Customs Administration. (2017). Electronic Personal Income Tax Return (eSZJA). National Tax and Customs Administration, available at: https://en.nav.gov.hu/taxation/eSZJA/ePIT.html

63. OECD (2015). Update on Voluntary Disclosure Programmes: A pathway to tax compliance. $O E C D$, available at: http://www.oecd.org/ctp/exchange-oftax-information/Voluntary-Disclosure-Programmes-2015.pdf

64. OJ C75. (2017). Opinion of the European Economic and Social Committee on 'Towards applying Nudge Thinking to EU Policies'. Official Journal of the European Union, C75, 28-32, available at: https://eur-lex.europa.eu/legalcontent/EN/TXT/PDF/?uri=CELEX:52016IE1333\&from=EN

65. Orbitax (2018). Lithuanian Provides Tax Amnesty for All Taxpayers. Orbitax International Tax Platform, available at: https://www.orbitax.com/news/archive.php/Lithuanian-Provides-Tax-Amnest-35897

66. Purcell, K. (2016). Applying Behavioural Economics in Irish Policy. Irish Government Economic and Evaluation Service, Department of Public Expenditure \& Reform, Staff Paper 2016, available at: http://budget.gov.ie/Budgets/2017/Documents/4.\%20Applying\%20Behavioural\%20Economics\%20 in\%20Irish\%20Policy.pdf

67. Reiss, J. (2013). Philosophy of Economics: A Contemporary Introduction. New York: Routledge.

68. Reumert, K. (2012). Denmark: Danish Tax Amnesty Available Until 30 June 2013. Mondaq: Connecting knowledge and people, available at: http://www. 
mondaq.com/x/195788/Income+Tax/Danish+tax+amnesty+available+until+ 30+June+2013

69. Rymanov, A. (2017). Tax amnesty in transition economy: Long-term trust or short-term revenues? International Journal of Contemporary Economics and Administrative Sciences, 7(1-2), 114-125.

70. Sánchez Huete, M. A. (2013). Medidas tributarias anticrisis de España. Análisis específico de la amnistía fiscal. Revista de Derecho, 26(1), 95-117.

71. Service, O., Hallsworth, M., Halpern, D., Algete, F., Gallagher, R., Nguyen, S., Ruda, S., Sanders, M., Pelenur, M., Gyani, A., Harper, H., Reinhard, J., \& Kirkman, E. (2014). EAST: Four Simple Ways to Apply Behavioural Insights. The Behavioural Insights Team, Cabinet Office, Nesta, available at: http:// www.behaviouralinsights.co.uk/wp-content/uploads/2015/07/BIT-Publication-EAST_FA_WEB.pdf

72. STEM. (2018). Veřejnost hodnotí EET i Účtenkovou loterii většinou pozitivně. Praha: Ústav empirických výzkumů, available at: https://www.stem.cz/ verejnost-hodnoti-eet-i-uctenkovou-loterii-vetsinou-pozitivne/

73. Sunstein, C. R. (2017). Nudges that Fail. Behavioural Public Policy, 1(1), 4-25, https://doi.org/10.1017/bpp.2016.3.

74. Supreme Audit Office of the Slovak Republic. (2018). Bločková lotéria pomohla vzdelávat', opatrenia vlády prispeli k boju proti podvodom na DPH. Bratislava: Najvyšši kontrolný úrad Slovenskej republiky, available at: https:// www.nku.gov.sk/tlacove-spravy-2018/-/asset_publisher/9KwBYFnI8E9P/ content/blockova-loteria-pomohla-vzdelavat-opatrenia-vlady-prispeli-k-bojuproti-podvodom-na-dph?inheritRedirect=false

75. Tax and Customs Board. (2017). Conference "SmartEST Taxation". Republic of Estonia, Tax and Customs Board, available at: https:/www.emta.ee/eng/ contacts-and-about-us/structure-tasks-strategy-board/conference-smartesttaxation

76. Tax and Customs Board. (2018). Information and News of E-Tax/E-Customs. Republic of Estonia, Tax and Customs Board, available at: https://www.emta. ee/eng/information-and-news-e-taxe-customs

77. TAXEDU. (2019). TAXEDU: Tax Builds my Future. European Union, available at: https://europa.eu/taxedu/home_en

78. Thaler, R. H., \& Sunstein, C. R. (2008). Nudge: Improving decisions about health, wealth, and happiness. New Haven; London: Yale University Press.

79. Torgler, B. (2004). Moral Suasion: An Alternative Tax Policy Strategy? Evidence from a Controlled Field Experiment in Switzerland. Economics of Governance, 5(3), 235-253, https://doi.org/10.1007/s10101-004-0077-7. 
80. Torgler, B. (2013). A Field Experiment on Moral Suasion and Tax Compliance Focusing on under-Declaration and Over-Deduction. FINANZARCHIV, 69(4), 393-411.

81. Ungureanu, D., M., \& Dascălu, E.-D. (2015). Improving VAT Compliance in Romania by Implementing a New Tool - Tax Lottery Receipts. Journal of Economic Development, Environment and People, 4(4), 47-57.

82. Williams, C. C., \& Franić, J. (2016). Beyond a Deterrence Approach towards the Undeclared Economy: Some Lessons from Bulgaria. Journal of Balkan and Near Eastern Studies, 18(1), 90-106, doi:10.1080/19448953.2015.1094269

83. Wilks, D. C., Cruz, J., \& Sousa, P. (2019) "Please give me an invoice": VAT evasion and the Portuguese tax lottery. International Journal of Sociology and Social Policy, https://doi.org/10.1108/IJSSP-07-2018-0120

84. Yaniv, G. (1999). Tax Compliance and Advance Tax Payments: A Prospect Theory Analysis. National Tax Journal, 52(4), 753-764.

85. Žunić Kovačević, N., \& Gadžo, S. (2017). Porezna amnestija kao instrument porezne politike. Društvena Istraživanja, 26(1), 101-122.

86. Žurovec, M. (2017). Informace o druhém slosování Účtenkovky. Ministerstvo financí České republiky, available at: https://www.mfcr.cz/cs/aktualne/ tiskove-zpravy/2017/informace-o-druhem-slosovani-uctenkovky-30407

87. Žurovec, M. (2018). Informace o třináctém slosování Účtenkovky. Ministerstvo financí České republiky, available at: https://www.mfcr.cz/cs/aktualne/ tiskove-zpravy/2018/informace-o-trinactem-slosovani-uctenkov-33503 


\title{
PREGLED KAKO SU BIHEVIORALNA SAZNANJA PRIMIJENJENA NA POREZNU POLITIKU I EKSPERIMENTE U EUROPSKOJ UNIJI
}

\begin{abstract}
Sažetak
Utaja poreza je problem u svakoj zemlji. Budući da su porezi najvažniji izvor prihoda državnog proračuna, ministri financija i porezna tijela nastoje povećati poreznu disciplinu i osigurati veće porezne prihode. U kontekstu ciljeva Europske unije za praćenje učinaka biheviorističkih spoznaja i prikupljanje podataka za kritičku procjenu, ovaj članak doprinosi tim naporima sažimajući politike i mjere povezane s povećanjem porezne discipline. Ovaj se članak temelji na sustavnom pregledu i nadopunjen je drugim relevantnim izvorima koji se odnose na primjenu biheviorističkih spoznaja u poreznoj politici. U članku se zaključuje da, iako postoje empirijski dokazi koji ukazuju na to da su inicijative i intervencije informirane o ponašanju imale značajan utjecaj na poreznu disciplinu u kratkom roku, nema dovoljno dokaza za donošenje zaključaka o dugoročnim učincima. Osim toga, stvarni motivi i uzročni mehanizmi koji su doveli do povećane porezne discipline nisu posve jasni. Rezultati istraživanja ukazuju na to da je odvraćanje važan čimbenik. Iako bi odvraćanje moglo povećati poreznu disciplinu, neizvjesno je ima li to pozitivan učinak na porezni moral općenito. U članku se iznosi argument da se mnoge tehnike informiranja o ponašanju zapravo temelje na odvraćanju. S tim u vezi, članak poziva na daljnja istraživanja kako bi se otkrili stvarni učinci biheviorističkih spoznaja. Daljnji rad na pregledu i ocjenjivanju rezultata istraživanja bit će također važan jer se pojedinačnim inicijativama u zemljama EU-a ne može lako ući u trag. Ova činjenica predstavlja granice ove studije i ističe mogućnosti za buduća istraživanja.
\end{abstract}

Ključne riječi: Bihevioralne javne financije, Europska unija, porezna amnestija, utaja poreza, porezna disciplina, porezna politika 